\title{
Simulated Cattle Injury to Planted Slash Pine: Defoliation
}

\author{
CLIFFORD E. LEWIS
}

\begin{abstract}
Animals sometimes injure trees by eating the leaves. Little is known about the amount of removal required to harm survival and growth, particularly of southern pines. To simulate a single defoliation by livestock or wildlife, needles of slash pine were hand clipped once at 6,18 , and 30 months after planting. Survival and height growth were measured for six growing seasons after removing $0,25,50,75$, and $100 \%$ of the foliage. Survival was excellent except when $100 \%$ of the needles were removed 6 months after planting. Reductions in rate of height growth occurred only with the most severe levels of defoliation and were still apparent for 3 years after treatment. Even so, the greatest accumulated loss in height was less than 1 m over the 6-year period.

Cattle and other animals sometime eat the foliage of trees, even resinous pine needles. However, Cassady et al. (1955) and Pearson (1976) observed that cattle rarely graze pine

\footnotetext{
The author is principal range scientist, Southeastern Forest Experiment Station Forest Service, U.S. Department of Agriculture, Marianna, Florida 32446.

This was a cooperative study by the Georgia Coastal Plain Experiment Station, University of Georgia, College of Agriculture, Tifton, Ga., and the Forest Service, USDA. Acknowledgement is given to Dr. Karl F. Wenger, whose idea prompted the

Manuscript received March 12, 1979.
} study, and to Ralph H. Hughes, who initiated the study.
\end{abstract}

foliage when other green forage is available. The quantity of needles eaten varies with rate of cattle stocking, abundance and variety of other forage, season of grazing, seedling condition at time of planting, and seedling size. Various attempts to assess needle removal under actual grazing conditions have been too imprecise to evaluate or to predict subsequent tree performance. However, an understanding of defoliation impacts is necessary in devising plants for integrated management of forested ranges. This study evaluates the impact of simulated defoliation by cattle on survival and height growth of slash pine (Pinus elliottii Engelm.). Five degrees of seedling defoliation were simulated by hand clipping at three plantation ages.

\section{Methods}

\section{Study Location}

The study was located in the Lower Coastal Plain at the Alapaha Experimental Range, Berrien County, Georgia, on a typical oldfield site that had not been cultivated or fertilized since about 1920 . Frequent burning and cattle grazing had produced a uniform cover of carpet grass (Axonopus affinis Chase). 


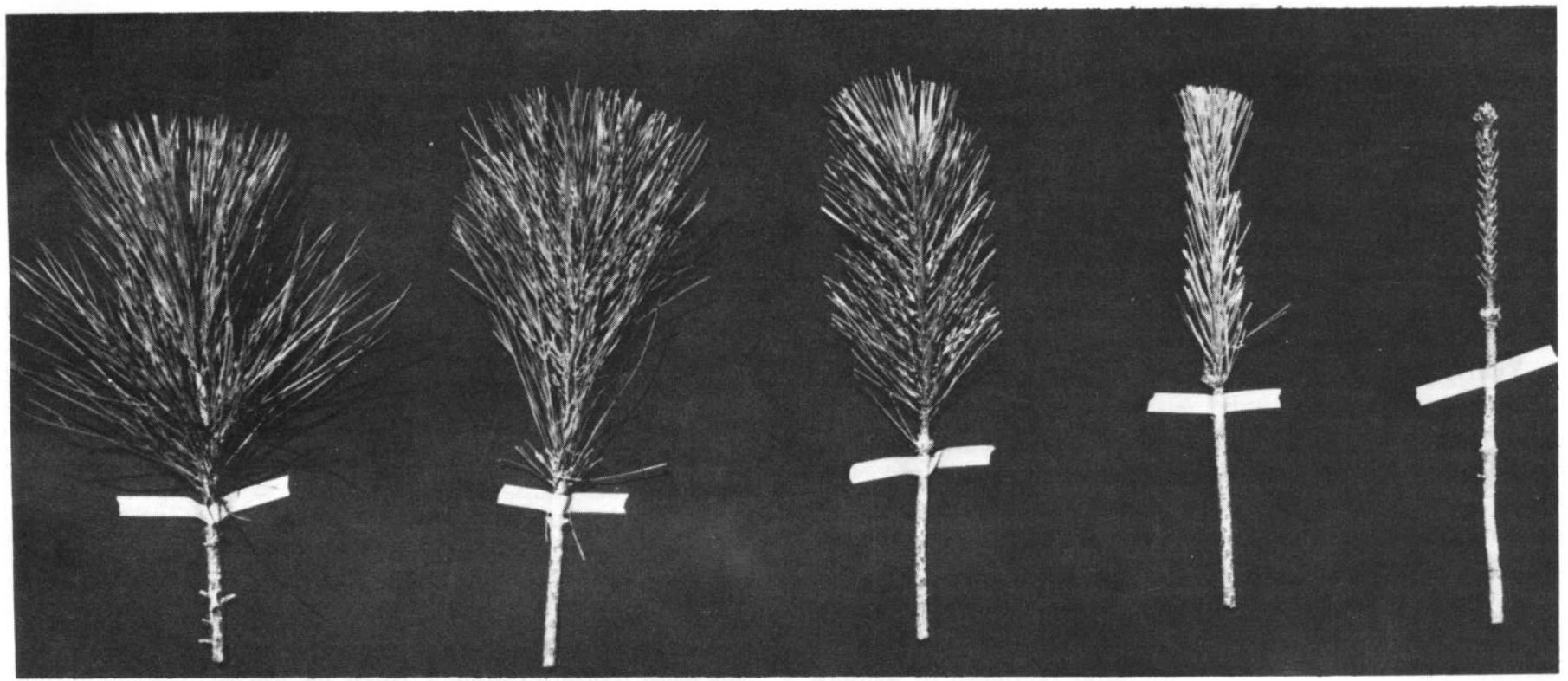

Fig. 1. Slash pine seedlings clipped 6 months after planting to remove 0,25, 50, 75, and 100\% of the foliage.

In 1958, a few large pines were removed from the site and burning was curtailed. The area was prepared for the first planting of seedlings in January 1960 by removing all stumps, cutting all weeds and small pines with a rotary mower, and installing a fence to prevent grazing. Mowing preceded each planting thereafter.

Soil at the study site is classified as Plummer fine sand, a very wet, acid, light-textured soil through which water moves freely in the upper horizons. Natural fertility is low. The Plummer series is a member of the loamy, siliceous, thermic family of Grossarenic Paleaquults (formerly classified as Low-Humic Gleys).

\section{Experimental Design}

The design was a split-plot randomized block with three replications. Treatments were applied to fresh groups of seedlings for 3 consecutive years; therefore, year-of-planting was the main plot effect. Each defoliation treatment was applied to seedlings 6, 18, and 30 months after planting. The three ages of seedlings at time of treatment were handled as separate tests. Treatments were assigned at random to transects of five trees separated by two or more trees; each plot was permanently identified.

\section{Treatments}

Healthy, 1-year-old slash pine seedlings were machine planted at a spacing of 1.2 by $2.4 \mathrm{~m}$ in January of 1960, 1961, and 1962 . Treatments were applied in late April to early June of 1960 through 1964 as soon as the new needles were fully developed.

Treatment consisted of clipping $0,25,50,75$, or $100 \%$ of the length of all needles on a seedling (Fig. 1). Treatments were applied only once to a seedling. Inferior, deformed, and diseased seedlings were removed while treatments were being applied and not counted as part of the transect.

During 1960 a heavy infestation of tipmoths (Rhyacionia sp.) and spider mites (Oligonychus sp.) developed despite spraying on May 23 with DDT ( $1 \%$ solution) and Kelthane ( $14.8 \mathrm{ml}$ per 3.8 liter of water). ${ }^{1}$ During 1961 through 1964 , therefore, all trees under 1.5 $\mathrm{m}$ tall were sprayed at monthly intervals from about March through August with a mixture of benzene hexachloride $(0.5 \%$ solution) and Kelthane ( $14.8 \mathrm{ml}$ per 3.8 liter of water). This combi-

This publication reports research involving pesticides. It does not contain recommendations for their use, nor does it imply that the uses discussed here have been registered. All uses of pesticides must be registered by appropriate State and/or Federal agencies before they can be recommended.

CAUTION: Pesticides can be injurious to humans, domestic animals, desirable plants, and fish or other wildlife - if they are not handled or applied properly. Use all pesticides selectively and carefully. Follow recommended practices for the disposal of surplus pesticides and pesticide containers. nation of insecticide and miticide eliminated these pests as a confounding factor affecting survival or growth.

\section{Measurements}

All trees were measured at time of treatment to establish initial tree heights at the beginning of the growing season and in October for six growing seasons thereafter. Survival was determined by counting living trees in each five-tree transect during each measurement period.

\section{Statistical Analyses}

Data on tree survival and height growth for each age-attreatment were subjected to an analysis of variance for a split-plot design. Percentage of survival was analyzed after arc sine transformation of the data. Differences were determined at the 0.05 level of significance. Tukey's $w$ procedure at the 0.05 level was used to test differences among means when the analyses of variances indicated that significant differences were present (Steel and Torrie 1960).

\section{Results and Discussion}

Survival

Removing all needles from slash pine at 6 months after planting killed $31 \%$ of the seedlings during the first year (Table 1). Total removal of needles seldom, if ever, occurs with browsing by cattle or wildlife. No other treatment significantly reduced survival, regardless of seedling age at time of treatment. Mortality resulting from lesser degrees of needle removal was no greater than is common in pine plantations of the South.

Similar survival for pine defoliation has been reported by other researchers. Clipping as much as $90 \%$ of the needles from young longleaf pine (Pinus palustris Mill.) caused no mortality (Bruce 1956). Low mortality of pine with grazing was reported by Pearson et al. (1971) and by Smith et al. (1958).

\section{Heights and Growth Rates \\ Clipped 6 Months after Planting}

Initial height at time of clipping averaged almost $0.2 \mathrm{~m}$ for seedlings treated at 6 months after planting (Fig. 2). After 6 years, trees that received the two most severe treatments were about $0.6 \mathrm{~m}$ shorter than other trees. 


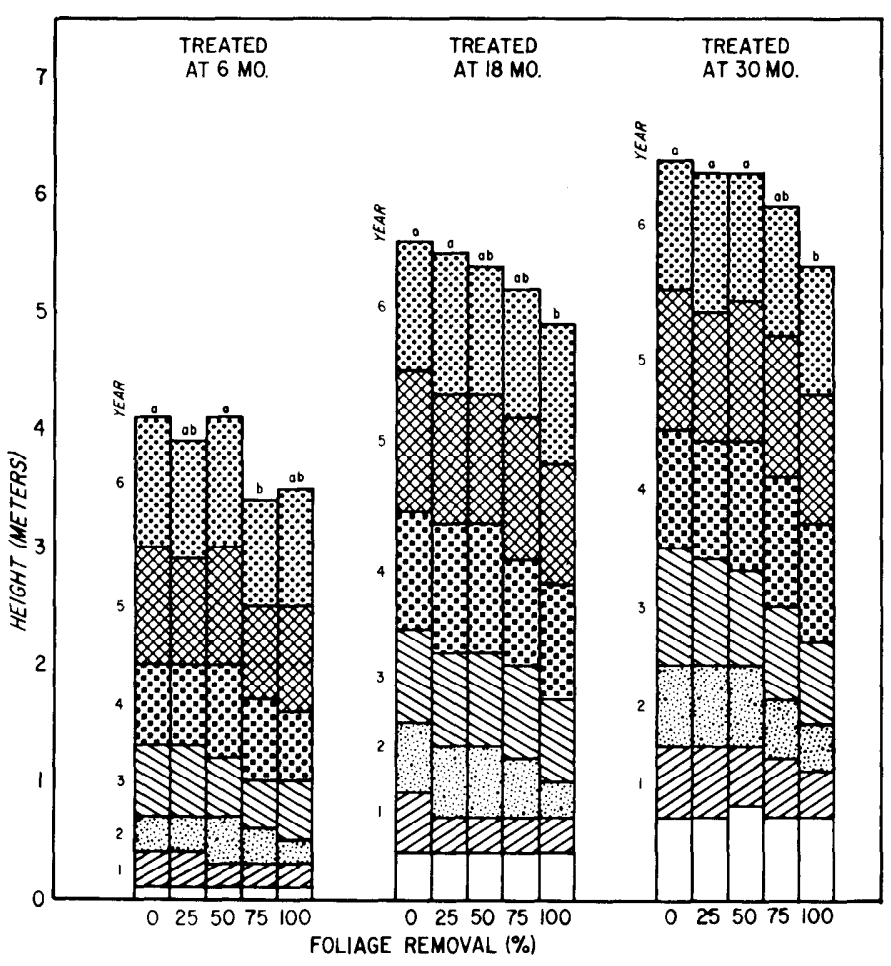

Fig. 2 Initial heights at time of treatment (bottom segments of bars), final heights, and annual growth for 6 years after five intensities of foliage removal from slash pine treated at three ages after planting. Within a given age-at-treatment, bars marked by different letters are significantly different at the $5 \%$ level. Detailed tables are available from the author.

\section{Clipped 18 Months after Planting}

Initially, trees defoliated at 18 months after planting averaged $0.4 \mathrm{~m}$ in height (Fig. 2). After 6 growing seasons, trees that received the most severe treatment were $0.7 \mathrm{~m}$ shorter than the control. Other differences in height were not significant.

During the first growing season, height growth was slightly reduced $(0.1$ to $0.2 \mathrm{~m})$ by all levels of defoliation. However, the greatest reduction in growth occurred during the second growing season, when trees that had received $100 \%$ defoliation grew significantly less $(0.5 \mathrm{~m})$ than in all other trees. A slight, but insignificant, carry-over was noted the third growing season. Thereafter, foliage removal had little effect on growth and all seedlings, regardless of treatment, grew at an acceptable rate.

\section{Clipped 30 Months after Planting}

Trees treated at 30 months after planting averaged $0.7 \mathrm{~m}$ in height initially, with no significant differences among treatments (Fig. 2). Complete defoliation had a more severe and longer laster effect when applied at 30 months after planting than when applied to younger seedlings; significant reductions in growth rate persisted through the third year. Although $75 \%$ foliage removal significantly reduced growth rates during the first 2 years, it caused no loss in growth thereafter. Less severe treatments had little impact on tree growth.

Since complete defoliation of slash pines resulted in poor recovery during the first year, it is surprising that they grew satisfactorily thereafter and produced acceptable trees (Fig. 3 ). With $50 \%$ defoliation or less, the trees recovered rapidly, showing no ill effects at the end of the study.

The effects of severe defoliation on all ages of seedling were apparent for only 2 to 3 years. Even during those years, the maximum losses in height growth averaged only about $0.2 \mathrm{~m}$ per year. With less severe treatment, the quick recovery and small losses in height growth supported observations by other researchers. Cassady et al. (1955) observed similar responses in grazed plantations of slash and loblolly pines. Hilmon et al. (1963) reported only small losses in height of slash pine that was grazed for 3 years after planting. Pearson et al. (1971) reported that grazing for 5 years after planting had no obvious effect on height growth of planted slash pine.

\section{Year of Planting}

Year of planting apparently influenced subsequent height and growth of seedlings. Initial heights of seedlings planted in 1962 and treated 6 months after planting were the same as those of seedlings planted in previous years. However, seedlings planted in 1962 and treated at 18 and 30 months showed some reduction in growth for about two growing seasons after treatment. In 1962, rainfall during the growing season (May through September) was about 10 inches less than the long-term average. Then during 1964, extremely heavy rainfall preceding and following treatment at 30 months kept the soil completely saturated. These rainfall conditions could help explain the poor recovery from defoliation and poor growth of seedlings planted in 1962.

\section{Summary and Conclusions}

The resistance of slash pine to defoliation indicates that, except under severe grazing pressure, grazing need not be eliminated from plantations for fear that livestock will reduce survival and potential wood yields. Quantitative data from this study provide resource managers with an idea of the eventual growth losses that may result from a single defoliation of slash pine by animals, insects, diseases, or fire. In planning integrated management of southern forests, managers can rely on slash pine being highly resistant to and quickly recovering from defoliation, particularly the rather minor defoliation associated with livestock and wildlife

Table 1. Survival (\%) of slash pine over a 6-year period as affected by 5 intensities of foliage removal at three plantation ages. ${ }^{1}$

\begin{tabular}{|c|c|c|c|c|c|c|c|c|c|}
\hline \multirow{2}{*}{$\begin{array}{l}\text { Foliage } \\
\text { removal }\end{array}$} & \multicolumn{3}{|c|}{ Treated 6 mo. after planting } & \multicolumn{3}{|c|}{ Treated $18 \mathrm{mo}$. after planting } & \multicolumn{3}{|c|}{ Treated $30 \mathrm{mo}$. after planting } \\
\hline & $1 \mathrm{yr}$. & 2 yr. & $6 \mathrm{yr}$. & $1 \mathrm{yr}$ & $2 \mathrm{yr}$. & $6 \mathrm{yr}$. & $1 \mathrm{yr}$ & $2 \mathrm{yr}$. & $6 \mathrm{yr}$. \\
\hline 0 & $100.0 \mathrm{a}$ & $100.0 \mathrm{a}$ & $100.0 \mathrm{a}$ & 100.0 & 100.0 & 100.0 & 100.0 & 100.0 & 97.8 \\
\hline 25 & $95.6 \mathrm{a}$ & $93.3 \mathrm{a}$ & 100 & $91.9 \mathrm{a}$ & 100.0 & 95.6 & 100.0 & 100.0 & 100.0 \\
\hline 50 & $100.0 \mathrm{a}$ & $100.0 \mathrm{a}$ & $93.3 \mathrm{a}$ & 100.0 & 100.0 & 97.8 & 100.0 & 100.0 & 100.0 \\
\hline 75 & $100.0 \mathrm{a}$ & $100.0 \mathrm{a}$ & $88.9 \mathrm{ab}$ & 100.0 & 100.0 & 97.8 & 100.0 & 100.0 & 97.8 \\
\hline 100 & $68.9 \mathrm{~b}$ & $68.9 \mathrm{~b}$ & $66.7 \mathrm{~b}$ & 97.8 & 97.8 & 97.8 & 100.0 & 100.0 & 93.3 \\
\hline
\end{tabular}

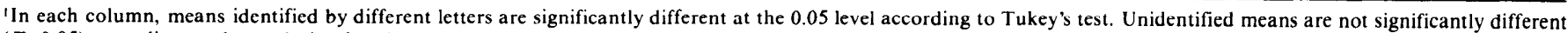
$(P>0.05)$ according to the analysis of variance. 


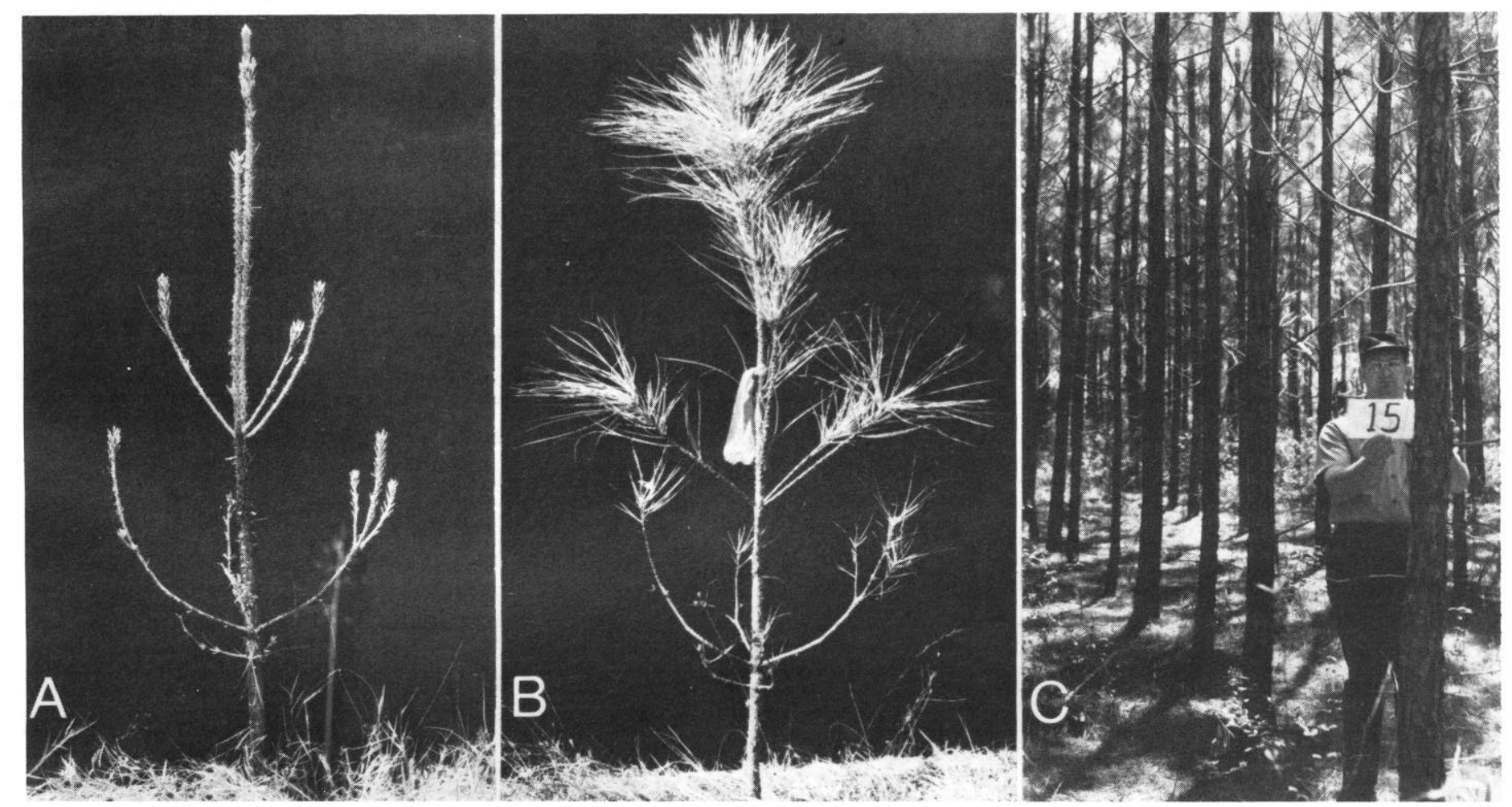

Fig. 3. Removing $100 \%$ of the foliage in May, 30 months after planting slash pine, $(A)$ resulted in poor recovery by the following October (B); after six

grazing when properly managed.

Survival was significantly reduced only when $100 \%$ of the needles were removed within 6 months after planting. Defoliation, regardless of intensity, had little effect on survival of older seedlings. Mortality in the years following treatment did not appear to be related to defoliation. It appears, therefore, that defoliation by animals has little effect on slash pine survival - even with removal of all needles. Several scientists have reported that cattle rarely graze pine needles (Williston 1974; Adams 1975); thus, causes other than foliage removal apparently should be associated with seedling mortality in grazed woodlands.

Height growth was reduced only by the most severe clipping. Effects were most apparent during the first and second growing seasons but sometimes persisted into the third year. Removing 75 and $100 \%$ of the needles had a longer lasting effect when applied 30 months after planting than on younger seedlings. The most severe treatment reduced heights about $0.9 \mathrm{~m}$ after 6 years. Less severe levels of defoliation generally reduced heights about $0.5 \mathrm{~m}$ or less after 6 years. These responses were similar to those reported by Hughes (1976) for South Florida slash pine (Pinus elliotti var. densa Little and Dorman), with two exceptions: (1) losses in early growth were not recovered as trees grew older and (2) sensitivity to defoliation did not decline in older trees. Fortunately, high levels of defoliation are less likely to occur on larger trees because animals cannot reach all the needles. The small amounts of needles typically browsed by cattle (Pearson 1976) would not reduce heights of slash pine.

Most wild and domestic animals will consume pine growing seasons, totally defoliated trees (5 trees behind technician) showed little effect of a single defoliation (C).

foliage only if they occupy areas with little green forage or with a limited variety of forages. In such situations, permanent damage could result, especially if the trees were repeatedly defoliated (Bruce 1956). When animal stocking is based on the available forage, however, little or no damage to planted pines results from grazing livestock. Adams (1975), in reviewing literature from all parts of the world, found that the primary need in forest grazing is to keep livestock numbers in balance with available forage.

\section{Literature Cited}

Adams, S.N. 1975. Sheep and cattle grazing in forests: A review. J. Appl. Ecol. 12: 143-152.

Bruce, David. 1956. Effect of defoliation on growth of longleaf pine seedlings. Forest Sci. 2: 31-35.

Cassady, J.T., W. Hopkins, and L.B. Whitaker. 1955. Cattle damage to pine seedlings. U.S. Dep. Agr. Forest Serv., South. Forest Exp. Sta. Occas. Pap. 141, 14 p.

Hilmon, J.B., C.E. Lewis, and J.E. Bethune. 1963. Highlights of recent results of range research in southern Florida. Soc. Amer. Forest. Proc. 1962: 73-76.

Hughes, R.H. 1976. Response of planted South Florida slash pine to simulated cattle damage. J. Range Manage. 29: 198-201.

Pearson, H.A. 1976. Botanical composition of cattle diets on a southern pine-bluestem range. U.S. Dep. Agr. Forest Serv., South, Forest Exp. Sta. Res. Note SO-216, 3 p.

Pearson, H.A., L.B. Whitaker, and V.L. Duvall. 1971. Slash pine regeneration under regulated grazing. J. Forest. 69: 744-746.

Smith, L.F., R.S. Campbell, and C.L. Blout. 1958. Cattle grazing in longleaf pine forests of south Mississippi. U.S. Dep. Agr. Forest Serv., South. Forest Exp. Sta. Occas. Pap. 162, 25 p.

Steel, R.G.D., and J.H. Torrie. 1960. Principles and Procedures of Statistics. McGraw-Hll Book Co., Inc., New York. 481 p.

Williston, H.L. 1974. Control of animal damage to young plantations in the South. J. Forest. 72: 78-81. 